\title{
INTRODUCTION
}

\section{Narrative abilities in bilingual children}

\author{
NATALIA GAGARINA \\ Center for General Linguistics (ZAS), Berlin
}

DALEEN KLOP

Stellenbosch University

IANTHI M. TSIMPLI

Aristotle University of Thessaloniki and University of Reading

JOEL WALTERS

Bar Ilan University

\begin{abstract}
ADDRESS FOR CORRESPONDENCE
Natalia Gagarina, Center for General Linguistics (ZAS), Schuetzenstrasse 18, Berlin 10117, Germany. E-mail gagarina@zas.gwz-berlin.de
\end{abstract}

The number of bilingual children is growing dramatically all over the world. In 2010 the International Organization of Migration documented 214 million migrants worldwide, many bilingual (Koser \& Laczko, 2010). One of the challenges arising from the rapid increase of bilingual children is scientifically grounded assessment of linguistic proficiency in both of a child's languages in various language domains. Assessment in both languages is especially important to avoid misdiagnosis of language impairment. Specific language impairment (SLI) is among the most prevalent impairments, estimated to affect 7\%-10\% of children entering formal education (Grimm, 2003; Tomblin, Smith, \& Zhang, 1997). Assessment tools for bilinguals in both the home language and the majority language are often lacking (for exceptions, see Gagarina, Klassert, \& Topaj, 2010; Schulz \& Tracy, 2011).

Language assessment of bilingual children is difficult, in part because there are very few normed instruments, and in many languages there are none. Because languages differ, assessment measures are not readily comparable and impairments may present differently in each of a child's languages. Narrative production, especially macrostructure features and mental/internal state terms, offer an entry point for examining the language abilities of bilingual children, which although they do not resolve all these dilemmas, do offer a starting point, as outlined here and described in the papers that follow.

Narrative abilities in children can be assessed in numerous ways. Narratives of different genres (e.g., personal or fictional) have been collected by a variety of

(C) Cambridge University Press 2015 0142-7164/15 
elicitation procedures, such as story generation/telling, story retelling, or telling a story after listening to a model story. Regardless of elicitation method, narratives are an ecologically valid way to investigate the linguistic and cognitive abilities that underlie narrative competence (Botting, 2002; Hughes, McGillivray, \& Schmidek, 1997).

Oral narratives provide a rich source of data about a child's language use in a relatively natural context; thus, narrative analysis allows linguists and clinicians to assess multiple linguistic features, including macrostructure (e.g., story grammar categories such as goals, attempts, and outcomes) and microstructure (e.g., lexical diversity, relational and referential devices, morphosyntax, and complex syntax) using relatively short language samples (Heilmann, Miller, \& Nockerts, 2010; Heilmann, Miller, Nockerts, \& Dunaway, 2010). There are also suggestions in the literature that narratives may be less biased and more appropriate for bilingual children than other language assessment tools, because "language tasks that require a cognitive component might . . . be tapping into language-general capacities" (Paradis, Genesee, \& Crago, 2010, p. 221).

Narrative skills are important for academic success, because they are an important discursive form through which academic information is disseminated and acquired. Narrative skills are also thought to bridge oral language and literacy by providing exposure to and experience in using extended, contextualized, cohesive discourse units and abstract texts (Hadley, 1998; Westby, 2005). Furthermore, discourse knowledge (including narrative) has been identified as one of seven critical components that directly or indirectly influence language and reading comprehension and account for variability in the reading achievement of individual children (Snow, 2002). According to Oakhill and Cain (2007), reading comprehension has its roots in the comprehension of narrative discourse that develops simultaneously with other early language skills prior to formal reading instruction. Intervention studies have shown that direct teaching of narrative skills improves comprehension and production of oral narratives as well as reading comprehension (Hayward \& Schneider, 2000; Swanson, Fey, Mills, \& Hood, 2005). Moreover, narrative abilities at the macrostructure level (i.e., at the level of formulation of cohesive event sequences) reflect capacities that go beyond the specifics of language. Thus, the assessment of narratives can be seen as especially appropriate for bilingual children.

\section{THE MULTILINGUAL ASSESSMENT INSTRUMENT FOR NARRATIVES (MAIN)}

The MAIN (Gagarina et al., 2012, 2015) was developed by the Narrative and Discourse working group of COST Action IS0804 (a pan-European research network) as part of the Language Impairment Testing in Multilingual Settings (LITMUS) test battery (Armon-Lotem, de Jong, \& Meir, 2015). After examining and evaluating a range of tasks used to elicit narratives and identify bilingual features in narrative discourse, a common set of pictorial stimuli, scripts, elicitation procedures, and scoring procedures was developed. The LITMUS-MAIN consists of four picture-based stories and scripts: Baby Birds, based on Hickmann (2003); Baby Goats, based on Guelzow and Gagarina (2007); Cat and Dog, both developed 
in the framework of this research. Each story is accompanied by a set of six pictures adjoined to each other in the form of a foldout book.

These pictorial stimuli, accompanying scripts, elicitation methods, and scoring procedures underwent more than 200 revisions and were piloted in over a dozen countries. The picture sequences were developed on the basis of linguistic and psycholinguistic criteria to elicit comparable narratives in the two languages of bilingual children. In general, the aim was to achieve parallelism across all four stories. Details controlled for included (a) protagonists: the number of protagonists, the timing of the introduction of new protagonists, their relative spatial position in the stimulus pictures and interaction with other elements in the picture (e.g., their size in relation to other objects), and the angle from which they were looking at the other protagonists; (b) background and foreground information: the protagonist's actions defined the foreground in each story and the pictures were of similar cognitive complexity and visual density; and (c) content: comparable onset, development, and conclusion of the storyline.

The goal was to construct an instrument that could be used to elicit narratives from children from diverse linguistic, socioeconomic, and cultural backgrounds as well as to enable researchers and clinicians to distinguish between bilingual children with and without SLI by making comparisons across languages/narratives, thus enhancing the validity and reliability of the measures.

The LITMUS-MAIN's picture sets and design allows for elicitation of narratives in three modes: telling a story (story generation); retelling a story after listening to it; and telling a story after listening to a different, but structurally parallel, model story. Three measures of macrostructure are assessed: story structure components, structural complexity, and internal states.

Each story contains three episodes defined by inclusion of the following components: goal $(\mathrm{G})$, attempt $(\mathrm{A})$, and outcome $(\mathrm{O})$, and strategically placed internal state terms as initiating events or reactions. Each episode depicts a single goal, attempt, and outcome and two internal state terms, yielding a total of 15 structural elements. Thus, in addition to setting (time and place), children's narratives were scored for production of these components as well as structural complexity, defined by Westby (2005) as (a) sequences (where no goal statement has been generated); (b) incomplete episodes (which include a goal statement, but lack a complete GAO structure due to omission of an attempt or outcome); and (c) complete episodes (including all three GAO components). The LITMUS-MAIN also provides a scoring protocol for internal state terms. Mental state language, grounded in Labov's (e.g., 1997) work on evaluation in narrative and in theory of mind research (e.g., Tomasello, 2003), is an indicator of the child's understanding and awareness of intentionality and goal-directed behavior of protagonists (Curenton \& Justice, 2004; Heilmann, Miller, \& Nockerts, 2010; Nippold, Ward-Lonergan, \& Fanning, 2005). This also allows comparability across languages.

The LITMUS-MAIN also includes criteria for scoring microstructure, including 10 features grouped into the following three categories: narrative length and lexis (total number of tokens with[out] mazes, number of different words/lemmas, and number of communication units), morphosyntactic complexity and discourse cohesion (mean length of communication units and of the three longest communication units), and syntactic complexity (the number and ratio of verb-based 
clauses, subordinating constructions, and coordinating constructions). In order to select the characteristics that might be relevant for assessing the language of bilingual children, these microstructure features were designed to be as similar as possible across stories. However, microstructure elements are largely language specific, and the examination of typological differences is beyond the scope of the papers here.

Finally, a set of comprehension questions that focus on macrostructure components and internal state terms also forms part of the LITMUS-MAIN. The comprehension questions assess goals and internal states (as initiating events and as reactions) from the story structure components. In addition, a set of background questions was developed (based on Gagarina et al., 2010) in order to evaluate quality and quantity of bilingual input.

\section{RESEARCH AIMS AND QUESTIONS}

The motivation behind the collection of papers in this Special Issue is to report on the initial findings from the LITMUS-MAIN, an assessment instrument with a conceptual framework that includes macrostructure/mental state terms, microstructure, and a common set of pictorial stimuli, elicitation procedures, and scoring methods aspiring to identify bilingual features in narrative discourse and to trace a developmental trajectory of narrative skills in the dual languages of bilingual children. The tool was pilot tested with more than 550 monolingual and bilingual children aged 3 to 10 , for 15 different languages and language combinations.

Narrative macrostructure deals with higher order hierarchical organization such as story grammar components and episodic structure (Heilmann, Miller, \& Nockerts, 2010). In contrast, microstructure focuses on linguistic features used in the construction of coherent discourse of a specific language (e.g., lexis, morphosyntax, referential and relational cohesion devices, and complex syntax). Thus, macrostructure and microstructure abilities represent two distinct but interrelated components of narrative discourse competence (Liles, Duffy, Merritt, \& Purcell, 1995; Pearson, 2002).

The research questions guiding the authors relate to cross-language comparisons of macrostructure/mental state terms and microstructure features, developmental differences, and task effects. Questions focused on cross-language comparisons and included the following:

- To what extent does children's performance differ across languages in terms of macrostructure, mental state terms, and microstructure features and story comprehension?

- Which macrostructure components and mental state terms best differentiate first language and second language production?

- To what extent is there evidence of transfer of narrative skills between languages?

- What is the developmental trajectory of the macrostructure elements (i.e., story structure categories, story complexity, and internal state terms), and to what extent does this trajectory differ across languages? 
Research questions that focused on group differences included the following:

- To what extent are there differences in performance between children of different ages, between monolingual and bilingual children, between simultaneous and sequential bilinguals and between children with typical language development and those with SLI?

The methodological questions centered on the following:

- How do story structure and mental state terms vary as a function of story content and elicitation tasks?

There is some evidence that macrostructure is universally acquired, even among bilingual children in both first and second languages (e.g., Gutierrez-Clellen, Simon-Cerejido, \& Wagner, 2008; Iluz-Cohen \& Walters, 2012; Pearson, 2001, 2002; Pearson \& de Villiers, 2005; Uccelli \& Páez, 2007). Based on these findings, a working hypothesis of the research group was that use of macrostructure categories should be relatively invariant across a bilingual child's two languages and should lead readily to cross-linguistic transfer, while lexical and morphosyntactic abilities should be more language specific and less predisposed to transfer. This hypothesis has been tested in other studies (e.g., Fiestas \& Peña, 2004; Iluz-Cohen \& Walters, 2012; Pearson, 2002; Uccelli \& Páez, 2007), but with highly varied and less comparable stimulus narratives and procedures.

The range of studies here shows a novelty in that they all use the same methodology and the same pictorial stimuli in eliciting narratives. The LITMUS-MAIN is innovative in that it was developed by a multicultural and multilingual team of researchers and allows for the evaluation of narrative skills in dual languages of bilingual children using similar stimuli for these languages. The studies in this Special Issue involve a common conceptual framework and a common set of materials and procedures, thereby more easily illustrating the kind of variation inherent in the investigation of bilingual children's language. One important contribution, which attempts to set an agenda for bilingual research, is the examination of both languages of bilingual children. Another is the range of languages and language pairs examined here. As indicated in the Foreword (Pesco \& Kay-Raining Bird, 2016 [this issue]), bilingual issues such as language dominance, proficiency, and exposure are barely touched upon in this set of papers. Nevertheless, this initial set of studies provides comparisons of monolingual/bilingual and simultaneous/sequential performance, and of performance at different ages, critical steps forward in reaching the long-term goal of an instrument to distinguish typically developing bilingualism from bilingual performance with SLI.

\section{REFERENCES}

Armon-Lotem, S., de Jong, J., \& Meir, N. (Eds.). (2015). Assessing multilingual children: Disentangling bilingualism from language impairment. Bristol: Multilingual Matters.

Botting, N. (2002). Narrative as a tool for the assessment of linguistic and pragmatic impairments. Child Language Teaching and Therapy, 18, 1-21. 
Gagarina et al.: Narrative abilities in bilingual children

Curenton, S. M., \& Justice, L. M. (2004). Use of literate language features in low-income preschoolers' narratives. Paper presented at the Head Start 7th National Research Conference, Washington, DC.

Fiestas, C. E., \& Peña, E. D. (2004). Narrative discourse in bilingual children: Language and task effects. Language, Speech, and Hearing Services in Schools, 35, 155-168.

Gagarina, N., Klassert, A., \& Topaj, N. (2010). Sprachstandstest Russisch für mehrsprachige Kinder/ Russian language proficiency test for multilingual children. ZAS papers in linguistics 54. Berlin: ZAS.

Gagarina, N., Klop, D., Kunnari, S., Tantele, K., Välimaa, T., Balèiûnienë, I., et al. (2012). MAINMultilingual Assessment Instrument for Narratives. ZAS papers in linguistics 56. Berlin: ZAS.

Gagarina, N., Klop, D., Kunnari, S., Tantele, K., Välimaa, T., Balèiûnienë, I., et al. (2015). Assessment of narrative abilities in bilingual children. In S. Armon-Lotem, J. de Jong, \& N. Meir (Eds.), Assessing multilingual children: Disentangling bilingualism from language impairment (pp. 241-274). Bristol: Multilingual Matters.

Grimm, H. (2003). Störungen der Sprachentwicklung: Grundlagen-Ursachen-DiagnoseIntervention-Prävention. Göttingen: Hogrefe.

Gülzow, I., \& Gagarina, N. (2007). Noun phrases, pronouns and anaphoric reference in young children narratives. ZAS papers in linguistics 48 (pp. 203-223). Berlin: ZAS.

Gutierrez-Clellen, V. F., Simon-Cereijido, G., \& Wagner, C. (2008). Bilingual children with language impairment: A comparison with monolinguals and second language learners. Applied Psycholinguistics, 29, 3-20.

Hadley, P. A. (1998). Language sampling protocols for eliciting text-level discourse. Language, Speech, and Hearing Services in Schools, 29, 132-147.

Hayward, D., \& Schneider, P. (2000). Effectiveness of teaching story grammar knowledge to preschool children with language impairment: An exploratory study. Child Language Teaching and Therapy, 16, 255-284.

Heilmann, J., Miller, J. F., \& Nockerts, A. (2010). Sensitivity of narrative organization measures using narrative retells produced by young school-age children. Language Testing, 27, 603-626.

Heilmann, J., Miller, J. F., Nockerts, A., \& Dunaway, C. (2010). Properties of the narrative scoring scheme using narrative retells in young school-age children. American Journal of SpeechLanguage Pathology, 19, 154-166.

Hickmann, M. (2003). Children's discourse: Person, space and time across languages. Cambridge: Cambridge University Press.

Hughes, D. L., McGillivray, L., \& Schmidek, M. (1997). Guide to narrative language: Procedures for assessments. Eau Claire, WI: Thinking Publications.

Iluz-Cohen, P., \& Walters, J. (2012). Telling stories in two languages: Narratives of bilingual preschool children with typical and impaired language. Bilingualism: Language and Cognition, 15, 5874.

Koser, K., \& Laczko, F. (2010). World Migration Report 2010: The future of migration: Building capacities for change. Geneva: International Organization for Migration.

Labov, W. (1997). Some further steps in narrative analysis. Journal of Narrative and Life History, 7, 207-215.

Liles, B. Z., Duffy, R. J., Merritt, D. D., \& Purcell, S. L. (1995). Measurement of narrative discourse ability in children with language disorders. Journal of Speech and Hearing Research, 38, 415-425.

Nippold, M. A., Ward-Lonergan, J. M., \& Fanning, J. L. (2005). Persuasive writing in children, adolescents, and adults: A study of syntactic, semantic, and pragmatic development. Language, Speech, and Hearing Services in Schools, 36, 125-138.

Oakhill, J., \& Cain, K. (2007). Issues of causality in children's reading comprehension. In D. McNamara (Ed.), Reading comprehension strategies: Theories, interventions, and technologies (pp. 4772). New York: Erlbaum. 
Gagarina et al.: Narrative abilities in bilingual children

Paradis, J., Genesee, F., \& Crago, M. B. (2010). Dual language development and disorders: A handbook on bilingualism and second language learning (2nd ed.). Baltimore, MD: Paul H. Brookes.

Pearson, B. Z. (2001). Language and mind in the stories of bilingual children. In L. Verhoeven \& S. Strömqvist (Eds.), Narrative development in a multilingual context (pp. 373-398). Amsterdam: John Benjamins.

Pearson, B. Z. (2002). Narrative competence among monolingual and bilingual school children in Miami. In K. Oller \& R. Eilers (Eds.), Language and literacy in bilingual children. Clevedon: Multilingual Matters.

Pearson, B. Z., \& de Villiers, P. A. (2005). Child language acquisition: Discourse, narrative and pragmatics. In K. Brown \& E. Lieven (Eds.), Encyclopedia of language and linguistics. Oxford: Elsevier.

Pesco, D., \& Kay-Raining Bird, E. (2016). Perspectives on bilingual children's narratives elicited with the Multilingual Assessment Instrument for Narratives. Applied Psycholinguistics, 37, 1-9.

Schulz, P., \& Tracy, R. (2011). Linguistische Sprachstandserhebung—Deutsch als Zweitsprache (LiSeDaZ). Göttingen: Hogrefe.

Snow, C. (2002). Reading for understanding: Toward a research and development program in reading comprehension. Santa Monica, CA: RAND Corporation.

Swanson, L., Fey, M., Mills, C., \& Hood, L. (2005). Use of narrative-based language intervention with children who have specific language impairment. American Journal of Speech-Language Pathology, 14, 131-143.

Tomasello, M. (2003). Constructing a language: A usage-based theory of language acquisition. Cambridge, MA: Harvard University Press.

Tomblin, J. B., Smith, E., \& Zhang, X. (1997). Epidemiology of specific language impairment: Prenatal and perinatal risk factors. Journal of Communication Disorders, 30, 325-342.

Uccelli, P., \& Páez, M. (2007). Narrative and vocabulary development of bilingual children from kindergarten to first grade: Developmental changes and associations among English and Spanish skills. Language, Speech, and Hearing Services in Schools, 38, 225-236.

Westby, C. E. (2005). Assessing and facilitating text comprehension problems. In H. Catts \& A. Kamhi (Eds.), Language and reading disabilities (pp. 157-232). Boston: Allyn \& Bacon. 